\title{
The Final Frontier: Guillermo Gómez-Peña’s The Great Mojado Invasion
}

Catherine Leen

Guillermo Gómez-Peña, who has been described as "without question the best-known Latino, Chicano, Mexican performance artist in the United States, Latin America, and the art world of the North Atlantic corridor," is a transnational figure in terms of both his biography and his work (Mendieta 2003, 539). Gómez-Peña has forged a composite identity as a Mexican-born artist who resides mainly in the United States and who describes himself as a "Mexican in the process of Chicanoization” (Gómez-Peña 2000, 21). His writings, performances, and filmic works, especially The Great Mojado Invasion (The 2nd US-Mexico War [2001]), which will be the focus of this chapter, seamlessly blend high and pop culture as he interrogates notions of cultural belonging and exclusion. Together with his long-term collaborators, Pocha Nostra, Gómez-Peña joins forces with performance artists and activists across the globe, producing works that create new spaces and communities through performances and Internet projects that transcend easy categorization in terms of race, gender, and even species. Given the fact that his own life has involved movements across borders of different kinds that are mirrored in his artistic practice, transnationalism provides a useful framework for the analysis of his work.

The use of the term transnationalism in close conjunction with globalization and internationalism means that it can be difficult to pinpoint its meaning. Paul Hopper notes that although religious beliefs, trade links, and diaspora communities predate globalization, transnationalism can be seen as both a consequence of globalization and a tool that can be used to study it, as it addresses "the formation of new social spaces and new types of community and 
forms of human interaction, as well as the adaptations to these developments that are taking place within specific contexts” (2007, 52). Conversely, Saskia Sassen sees “economic, political, and cultural globalization as transnational processes” (2007, 1). Basch, Glick Schiller, and Szanton Blanc have defined transnationalism as "the processes by which immigrants forge and sustain multistranded social relations that link together their societies of origin and settlement, and through which they create transnational social fields that cross national borders" (qtd. in Kelly 2003, 210). The definition of transnationalism is taken further by Wuthnow and Offutt, who argue that border crossings are not a prerequisite for experiencing transnationalism:

People who are not themselves recent immigrants or located in diasporic border towns are also influenced by globalization. They watch CNN, travel, visit friends and relatives in other countries, work for multinational corporations, and purchase goods from abroad. They live in a world in which transnationalism is very much present. If they are not themselves immigrants, they are increasingly involved in an economy based on transnational flows of labor and capital.

(Wuthnow and Offutt 2008, 210)

Gómez-Peña’s work involves both literal and metaphorical border crossings. His exploration of transnationalism takes into account the interactions between diverse communities that predate the nation-state era mentioned by Mendieta, most notably through the use of language and religion as metaphors of cultural exchange and transformation. The media through which he constructs his works are also very significant. He uses video and film, which have traditionally been the tools of a mainstream entertainment industry centred in the United States, and the Internet, which provides the type of virtual transnational space mentioned by Kelly. The 
use of the combination of these media in The Great Mojado Invasion is not incidental, for Néstor García Canclini has noted that:

Donde se ve más efectiva la globalización es en el mundo audiovisual: música, cine, televisión e informática están siendo reordenados . . . para ser difundidos a todo el planeta. El sistema multimedia que parcialmente integra estos cuatro campos ofrece posibilidades inéditas de expansión transnacional aun en las culturas periféricas.

(García Canclini 2005, 15). ${ }^{1}$

This collision of mass-market global forces with the independent and even anarchic possibilities of cyberspace was highlighted in a truly unprecedented manner in 1994 when the North American Free Trade Agreement NAFTA came into effect in Mexico. This trade agreement between the United States and Mexico followed the pattern of other such global alliances by subsuming Mexico's economy, including its film industry, to North American multinationals. What was unique about the formal implementation of the agreement was that it coincided with a deliberately timed protest by the Zapatista Army of National Liberation, which underscored the gulf between those who sought to profit from globalization and a subaltern sector of Mexican society that had been neglected and oppressed for decades so that the "Mexican past had again become the present" (Suchlicki 2008, 148). Not only was the Internet crucial in spreading the word of the Zapatista uprising but it was used to great effect by Subcomandante Marcos to outline the group's demands and philosophy. Moreover, the government was powerless to contain the constant updates on the struggle, which could be accessed from all over the world (Green 1997, 102).

Gómez-Peña’s 1990 work, Border Brujo, featured a transnational culture clash similar to that between the premodern social position the Zapatistas were forced into and the contemporary 
globalized world represented by NAFTA. This video of a performance piece, made in collaboration with filmmaker Isaac Artenstein, casts Gómez-Peña as a postmodern shaman who has the power to conjure a vertiginous range of identities, both through changes in his own costume, voice, and attitudes and through the kaleidoscopic cultural symbols that adorn his chaotic altar. Claire F. Fox notes that the video marked an important development in the artists' work by moving away from conceiving the border as a particular physical space to a "re-casting of the border as a global and temporal zone” $(1999,130)$. What is most striking about the piece is the constant shifting between not just Spanish and English but between languages as diverse as French and Náhuatl and even the simulated speaking in tongues. The work is also notable for the direct and at times confrontational engagement with the audience, which challenges them to consider their own prejudices, stereotypical views, and fears about the Other. Fox also points out that "Gómez-Peña is not out to destroy differences so much as he attempts to effect abrupt collisions among various 'subject positions,' and to compel his audience to perform a similar kind of 'border crossing'” (1996, 233-234). The conflation of so many different visual images and voices amounts to a deconstruction of the idea of a dominant culture, as all are given equal space and at times even overlap. This inclusive approach also rejects clearly differentiated boundaries between Mexican indigenous and Western cultures, creating a hybrid transnational space where unexpected juxtapositions of disparate cultural symbols begin to seem mundane.

The artist's more recent filmic work, The Great Mojado Invasion, made in collaboration with the filmmaker Gustavo Vasquez, is to some extent a more straightforward piece in that it purports to be a documentary about Chicano history. It is decidedly more narrative-driven than Border Brujo, but its revisionist view of history leads to an imagined scenario in which the Latino population dominates the United States. Furthermore, the film's use of clips from both 
mainstream and what could generously be categorized as B-movies, predominantly low-budget Mexican science-fiction movies, implicitly calls into question the sources on which any historical account is based.

“Space: The Final Frontier," the famous opening line of the voiceover from the Star Trek series, could serve as an introduction to Gómez-Peña’s frequent recourse to the science-fiction genre as a vehicle for exploring racial conflicts in The Great Mojado Invasion. The artist has used science-fiction characters on many occasions to communicate the sense of dislocation and marginalization he felt when he first came to live in California: "We were the undisputed backbone of the economy and the omnipresent bogeyman in the Anglo imagination. We were California's romantic backdrop and favourite food, and at the same time we were its epic fear: a gallant mariachi morphing back and forth into Godzilla” (Gómez-Peña n.d.). Doubtlessly, the marginal position of science fiction as a form that has often been viewed as less than tasteful or acceptable as art would also have appealed strongly to him. William Johnson observes that "although science fiction writing has gained enormously in popularity and critical attention in recent years, it is still not fully respectable," and adds that "screen science fiction is in an even more dubious position” $(1972,1)$. If science fiction is considered a less than highbrow genre, paradoxically, it has occupied a notable role in reflecting the fears and tensions of the societies it depicts:

Critical works have focused on the way in which SF and horror films articulate an anxiety about progress, as well as social and cultural concerns contemporary to the text, such as Cold-War narratives, race and gender issues, and also the changing conception of humanness in a technological environment.

(Wood 2002, 13-14) 
Science-fiction films essentially mirror the concerns of contemporary society, most often in terms of threats from other nations that are played out in Outer Space or through tales of unwelcome invasions, but they also articulate concerns closer to home, particularly racial ones. Charles Ramírez Berg, in his study of the place of Hispanics in science-fiction films, asserts that the stereotyping of Hispanics since the era of silent cinema has led to a perceived need in contemporary cinema to eliminate aliens either by returning them to their own planets or by destroying them $(2002,158)$.

The strong association between Mexicans and aliens has led numerous Chicano/a artists to explore the possibilities the stereotype offers. In their 1998 play Bordertown, theatre collective Culture Clash presents a scenario in which heated discussions of the racial tensions between Mexicans and Anglos are interrupted by the arrival of "an intense Bald Man wearing a purple cosmic gown and Nike sneakers” $(2003,17)$. This figure exhorts the humans he encounters to leave behind the physical and metaphorical borders that separate them and encourages them to start a new life in a "borderless cosmos, where race, creed and religion does not matter" (18). The play concludes, after much fraught negotiation of identity politics between a diverse cast of characters, with the reemergence of the Bald Man, whose speech explicitly links Aztec cosmology with the promise of an escape from ethnic divisions:

The New millennium marked the close of a major cycle and will initiate a spiritual renaissance of logic and reason. The end of the millennium is also the end of the Dark Ages, what the Aztecs call "El Quinto Sol.” As we enter this new era, we must leave behind the negative feelings of our lower self. The hatred, the fear, the unresolved conflicts. Our ancestors know of a place, a place where there are no borders, only infinitesimal possibilities. 


\section{(Culture Clash 2003, 63)}

The use of the present tense "know" in the final sentence is significant, for it underlines the fact that Aztec wisdom is not something confined to history, but a living philosophy that illuminates a way forward by transcending racial boundaries and embracing the possibilities of the entire universe through space travel. Space in this work is thus constructed as a utopian alternative locale where borders are replaced by possibilities. On a far less optimistic and frequently acerbic note, Los Angeles-based cartoonist Lalo Alcaraz has made use of images of aliens to highlight the marginalization of Latino/as in U.S. society. A typical strip, titled “Alienated,” features images of an extraterrestrial accompanied by the caption: “I don’t get it. The government denies I exist ... Hollywood vilifies me . . Businesses exploit me for profit ... You'd think I was Latino!” (Alcaraz 2004, 81). What is notable about Alcaraz's work is his frequent use of the alien-immigrant association to underscore and question the strong link between these terms that has largely been created by Hollywood filmmakers. One such example is Barry Sonnenfeld’s 2002 Men in Black, which features a scene where an extraterrestrial villain attempts to enter the United States disguised as an undocumented Mexican. Ramírez Berg comments further on this association is his discussion of Superman, whom he designates as one of the few exceptions to the rule that aliens must be expelled from the United States because of his exceptional talents, which benefit U.S. society and thus allow him to be welcomed and naturalized:

The narrative trajectory of the ... Superman series allows us, then, to see a crucial immigrant/native trade-off. America will drop its isolationist barrier to get something uniquely valuable. The Alien, in exchange for their acceptance, must do what generations of aliens have been called on to do for centuries_-assimilate. 
(Ramírez Berg 2002, 167)

Gómez-Peña is at the forefront of artists who have long recognized the potency of stereotypical visual representations of Latinos as aliens and used them to great effect to examine the complexities and conflicts resulting from transnationalism. The diasporic communities described in neutral terms by theorists of transnationalism literally mutate in his work, as Mexican Americans become threatening extraterrestrials or part-cyborg creatures who threaten U.S. security and civilization, while at the same time having an undeniable exotic appeal. Similarly, the calm discussion of globalization and the media is problematized in his writings, films, and performances by the questioning of hierarchies of film genres, with kitsch Mexican Bmovies being afforded the same authority as slick Hollywood productions or earnest art films in The Great Mojado Invasion. This unveiling of the manipulative power of the mass media is accompanied by an extremely inventive use of Internet-based media creations, so that the globalization of the media is presented simultaneously as a hegemonic force of global capitalism and a tool for protest and the presentation of alternative perspectives. Moreover, the very presentation of transnational processes in a seemingly detached, academic manner is parodied by his use of popular culture, particularly science fiction, combined with an acerbic sense of humour.

In his 1996 book Friendly Cannibals, Gómez-Peña presents Superman, joined in one case by Captain America, repelling foreign invaders in the form of Mexican pre-Columbian deities, thus conflating a U.S. popular-culture icon with a pre-nation-state figure that represents an ancient and profoundly religious culture. A similar image in the same book follows Ramírez Berg's description of the acceptable alien as Superman, clad in cowboy garb, faces off against another pre-Columbian God. In both cases, Superman, who in the second instance is made all the 
more human by his cowboy outfit, is the defender of the U.S. nation against a far more pernicious alien threat than he himself represents, thus becoming a supernatural cowboy defeating marauding Indians. Gómez-Peña has also created his own range of half-human, halfrobot characters, which blend features from famous science-fiction characters with Mexican traits. In Dangerous Border Crossers: The Artist Talks Back, he introduces one such character, the Mexterminator or El Mad Mex:

Features: Illegal border crosser and cultural invader, defender of immigrants' rights, drug and jalapeño pusher, practices boxing, Tex Mex rock and narcoshamanism, seduces gueras [blondes] and abducts innocent Anglo children. Sponsored by the Gulf Cartel and the Zapatista movement. Wanted by the DEA, the FBI, the INS and the Smithsonian Institution. Indestructible!

(Gómez-Peña 2000, 44)

The Mexterminator is a futuristic, cyber creation who nonetheless conforms to the timeworn stereotype of a criminal Mexican, who crosses borders illegally, pushes drugs, and preys on Anglo women and children. Yet he is also of interest to cultural historians and anthropologists, thus he clearly has a desirable exoticism. Notably, he is explicitly linked to the Zapatistas, thus suggesting the political power that can be channelled through the use of the Internet. Most chilling from the point of view of mainstream society is his unstoppable drive to disrupt U.S. social order, which is indicated not only by his association with a drug cartel but through the superhuman attributes his half-human, half-cyborg identity imply. His ruthlessness and superhuman powers distinguish him from the usual derogatory but essentially unthreatening stereotypes of Mexicans: 
En Estados Unidos los estereotipos pasivos del “sleepy Mexcan,” el "greaser” y la "border señorita" se descongelaron en la década de los ochenta. A partir de la implementación (aún ilegal) de la propuesta 187 y la nueva fiebre antiinmigrante surge el Nuevo estereotipo del Mexican: el recién nacido robo-Mexican encarna los temores xenofóbicos de una sociedad exprimermundista (en proceso de tercermundización) y viene a reeemplazar al formidable enemigo soviético debutando en la pantalla grande y en el Super Nintendo II: Se trata del Mexterminator, alias el Mad Mex . . . Su siniestra misión es ni más ni menos que la reconquista del suroeste de gringolandia; y ni Stallone, ni Schwarzennegger, ni Pete Wilson lo pueden detener.

(Gómez-Peña 2002, 104) ${ }^{2}$

Two other recurrent characters who share these superhuman qualities are Super Pocho, played by Roberto Sifuentes, and El Aztec High-Tech, who appear in the performance piece the New World Border, which envisages a future where: "The U.S.-Mexico border disappears, Spanglish becomes the 'official' language; the hybrid state is now a political reality; and the ethnic/social pyramid has been turned upside down” (Gómez-Peña 2002, 44). This vision of a future populated by cyber-enhanced Mexican superheroes who relegate Anglo English speakers to a subaltern class is the realization of the fears provoked by literal and virtual transnational exchanges. Gómez-Peña has pondered this role reversal between the power positions of Mexicans or Mexican Americans and North Americans on numerous occasions, but nowhere does the idea achieve such a dramatic enactment as in The Great Mojado Invasion. This frenetically paced and frequently hilarious film showcases Gómez-Peña’s unique ability to manipulate pop cultural images and ideas into his work and recast them in such a way as to make his audience consider serious issues related to transnational conflict. 
The film features Gómez-Peña as a narrator whose commentaries punctuate what purports to be a documentary about the second U.S.-Mexico war, which is won this time by Mexico. It is divided into seven chapters that span the period from before the arrival of the Spanish to the Americas to the late twentieth century, thus charting the decline of the Mexican people from an idyllic existence in pre-Columbian Mexico to the current disenfranchised state of their descendants. The ordered temporary progression and use of the documentary genre belie the chaos that is unleashed by the filmmakers. Dressed in a trilby hat, tie, shirt, and waistcoat, Gómez-Peña reproduces the serious and formal look of the documentary expert spokesperson, although his words could not be less measured, and he is already smoking and drinking beer. His intermingling of Spanish and English points to the transnational nature of the piece, as it presents U.S.-Mexican history from the perspective of the vanquished and in both languages, as well as through the distinctive code switching associated with Chicano/a culture. The liberal use of influences from myriad cultures is suggested immediately after this address, as the phone number 1-800-369-VATO appears on screen accompanied by jaunty Asian music and a voiceover that is not translated. This scene fades to an image of naked mariachis whose guitar playing is drowned out by a rousing science-fiction instrumental. The first real indication of how central humour will be to the film comes after this, when a title announces: "Finally, the uncensored version of the director's cut of the Chicano sci-fi classic banned in 69 festivals.”

Thus far, the standard documentary device of the authoritative commentator, the use of what is presented as archival film footage, and the language of advertising have been parodied through the lurid presentation of all of these elements in a way that highlights their artifice and undermines the claim of documentary to present an objective, unmediated truth. This foregrounding of the apparatus of the film also underscores the fact that all too often people of 
color are presented by white filmmakers as an exotic but primitive other unable to tell their own stories:

The people depicted in an "ethnographic film" are meant to be seen as exotic, as people who until only too recently were categorized by science as Savage and Primitive, of an earlier evolutionary stage in the overall history of humankind: people without history, without writing, without civilization, without technology, without archives.

(Rony 1996, 7)

By taking on the role of narrator, Gómez-Peña makes it clear that his is a history of the Mexican and Chicano people told from a Mexican perspective. Moreover, his use of rarely identified, B-movie footage as his archives playfully suggests the shortcomings of this approach, which depends on the privileging of certain sources of information over others. The betterknown films he includes often feature ethnic groups seen through the eyes of Westerners, such as the infamous Dances with Wolves, whose sympathetic view of Native Americans is fundamentally undermined by the casting of Kevin Costner as a white man who becomes an accepted member of a Sioux tribe. Jon Landis's The Three Amigos, while to some extent successful in parodying the U.S.-centered approach to Mexico embodied in the film it satirizes, The Magnificent Seven, ultimately still portrays the U.S characters as superior to the hapless Mexicans they save. Even Nicolás Echeverría’s much-praised Cabeza de Vaca does not escape parody, this time for its overly earnest anthropological approach, which despite its focus on a case where the conquerors become the conquered still has the Western characters as the protagonists. The use of documentary elements here also follows on from Third Cinema in its irreverent attitude to the genre and the use of it as a starting point for a highly inventive transnational cinematic portrayal of history in a manner akin to that described by Ana M. López: 
[A]lthough the New Latin American Cinema has activated almost every mode, genre and style of cinematic production, documentary realism—as transformed by different contextual pressures-has served as a springboard for the movement's transformation and retheorizing of the cinematic apparatus and its social functions. Eschewing the traditional distinctions between documentary and fictional modes of filmmaking in its search to produce a "new" cinema with a renewed social function, the New Latin American Cinema has questioned, juxtaposed, transposed, and, ultimately transformed each mode so that their various ontological and epistemological claims are mediated by the forces of past and present historical contexts.

(López 1990, 404)

The New Latin American Cinema, itself an extremely diverse movement, was a key influence on early Chicano filmmaking in its insistence on the making of formally and thematically radical films. This influence is suggested in the fact that Francisco X. Camplis's key early essay "Towards the Development of a Raza Cinema” cites Fernando Solanas and Octavio Getino’s seminal essay “Toward a Third Cinema” (Camplis 1992). The films included in The Great Mojado Invasion, especially Cabeza de Vaca, emulate this formal experimentation but insistently present events from the point of view of the dominant Western culture.

The first radical departure from the realism so often taken for granted as part of documentary occurs in Chapter Two, when science fiction emerges as a major element in the film. The conquistadors are introduced as Euro-Aliens by means of a shot of Spanish galleons arriving in Hispanola, which is preceded by one of Godzilla emerging from the sea. GómezPeña's voiceover further emphasizes the idea of the Spanish as the original undocumented immigrants: "One day the first illegal aliens began to arrive in the tropical shores of our still 
unnamed country.” Chapter Five develops the science-fiction elements of the film further, adding credence to the idea that Mexicans are indeed not just outsiders but extraterrestrials. Here, the voiceover tells us that:

By the early 1990s, U.S. dictator Jorge Bush began to figure it out. Yes, the art world was a cover-up for anti-American radicals. Yes, there was an occult cofradie of people of colour holding undeserved positions of power and yes, there was in fact a ChicanoMexicano conspiracy y para acabar de joder [to stop fucking around] the Mexicans were, yes, we were aliens, extra- extraterrestres. We had an extra gene with the enigmatic name of X-209.

The apparent revelation that Mexicans are creatures from another planet is intensified by the accompanying images of government agents, El Aztec High Tech, and a Mexican man and woman morphing back and forth from alien to human forms. The film goes on to conflate images of Mexican sombreros with flying saucers and to suggest that, like El Mad Mex, these creatures were predatory and dangerous and had to be targeted by a special FBI task force, as the voiceover explains: "The FBI created an especial archive strictly for cases of abduction of rural housewives by Mexican nationals. It was called ni más ni menos que (no more and no less than) the Mex files."

Gómez-Peña’s deliberately absurd rewriting of history presents as fact the idea that Mexicans are extraterrestrials infiltrating North American society and politics. It takes the science-fiction stereotype of the alien to its logical extreme-if Mexicans are indeed aliens, then they are threatening, monstrous figures who represent the fears of a society where clear-cut identities are already being erased by transnational encounters and cyberspace. By embracing this ludicrous idea of Mexicans as extraterrestrials and turning it into a pseudo-historical account, 
he robs it of its potency and exposes its absurdity. Despite the reversal of roles in the film, the newly dominant position of Chicano/as is not a positive development, however, for as Chapter Seven reveals, under the leader Gran Vato, the new Mexican and Chicano elite behave as badly toward Anglos as they themselves were previously treated. The voiceover explains:

By late 99, gringos had been reduced to nomadic minorities derogatively called Waspbacks. After the signing of the Guadalupe Marcos treaty, they began to cross illegally the new border . . . to work for fast-food taquerías for less than 200 pesos an hour. The civil, labor and sexual rights of these downtrodden minorities were constantly violated and there was no embassy to defend them. Those who chose to stay in the U.S. of Aztlán, meaning on this side of the border, were forced to live underground, their language, el inglés, was outlawed by the controversial PROP 69 y por debajo [and lower down].

Not only are the rights of Anglos utterly abused in this new world order, but they are misrepresented by the media and, like Mexicans and Mexican Americans before them, subjected to a derogatory stereotyping described as follows in the voiceover: "The hegemonic Chicano mass media began to portray them, Anglos, as socially impaired, culturally alienated and prone to unnecessary violence." Ultimately, the now extremely drunk narrator is forced to acknowledge that merely swapping roles and becoming the oppressor rather than the oppressed, achieves nothing:

Can you pinche believe it? Soon it became clear that the new Revolution-junta was—iay, me duele decirlo! [Oh! It pains me to say it!]—reproducing the same behavior and patterns of the old order. And something had to be done. So, so many of us decided to go 
underground once again and form the new hybrid militia to oppose the reverse authoritarianism of the new regime.

Cutting to a clip of a Mexican wrestler mask, the film ends with an image of Zorro, escaping capture once more and riding off into the horizon with a cheery salute to his adoring public.

The hilarious montage of clips used throughout The Great Mojado Invasion ultimately leads to a cultural flattening, so that the boundaries between mainstream films, such as Dances with Wolves, and B-movies, such as unnamed Mexican vampire films, become blurred, especially as the film is punctuated by appearances from Gómez-Peña’s own science-fiction creations, El Mad Mex and El Aztec High Tech. The fact that the so-called archival footage is from Mexican, U.S., and other sources also avoids the polarization of the two nations and opens the discussion of racism and social inequality to extend beyond the either/or proposition that is seen to be the failure of the new Chicano regime, which merely replaces one hegemony with another. Finally, the manipulation of film and computer technology by the filmmakers calls into question the idea of Mexicans as a primitive, backward people while at the same time underlining the pervasive and damaging manipulation of racial issues by a sensationalist mass media. There is also a distinct echo here of the use of Internet technology by the Zapatistas to confront encroaching globalization by powerful multinational firms. The fact that the pseudodocumentary is narrated and indeed compiled by Gómez-Peña, aided by his cyber creations, points to the possibilities offered by technology as perhaps the ultimate egalitarian bordercrossing device. In the end, what is most successful about the film is its ability to make thoughtprovoking and insightful arguments about injustice, racial stereotypes, and the abuse of power through a hybrid mix of science fiction and documentary that never ceases to be entertaining. In this acknowledgement of the power of humor, Gómez-Peña’s most important precursor is 
perhaps Cheech Marin, who pioneered the use of self-directed stereotyping in his Cheech and Chong films, and in the classic comedy Born in East L.A. Marin has commented on the unique potential of humor to communicate a social message in an appealing way:

I believe that important subjects can be dealt with as entertainment . . . throughout film history, comedians have often been the first ones to bring issues to the public. Underneath that mask of humor, a lot of comedians are moralists, because it’s easier to get somebody to look at a problem is they can laugh first and think later.

(qtd. in West and Crowdus 1988, 38)

Gómez-Peña clearly follows this approach, and he is also acutely aware of reaching a North American public by recycling their popular cultural references in a way that may be amusing but is also unsettling. When asked by Latino philosopher Eduardo Mendieta about how he reacts to the way in which the cooption of Latino images by a global media creates stereotypes that are far removed from the reality of Latino experience, he comments that the real challenge he and other artists face is reconciling the tension between reaching and alienating mainstream audiences:

How do we continue raising crucial issues without scaring the audiences or without facing deportation back to the margins? My answer, for the moment, is that we must mimic mainstream culture, and when the mirror is standing between them and us, reflecting their fantasies and desires, we break it in the audience's faces. If parts of the mirror get in their eyes, that's their problem.

(Mendieta 2003, 549)

Essentially, his use of so many transnational cultural references that would be familiar to North American audiences lulls them into a false sense of security before exposing them to a 
recasting of these well-known characters and scenarios in an outrageous rewriting of history that may be amusing but is also profoundly disturbing. This confrontational attitude toward the audience recalls the challenges put to the audience of Border Brujo, though The Great Mojado Invasion develops this challenge further. As Fox notes, Border Brujo is not a particularly innovative piece formally, as it “privileges documentation of Gómez-Peña’s performance over experimentation with the video medium itself” $(1999,123)$. The Great Mojado Invasion mixes mainstream and low-budget films with performance and cyber characters created on the Internet so that the idea of borders between media are blurred and even erased, thus creating not only a deeply revisionist history of the place of Chicano/as in U.S. culture but also pointing to the radical transformative effects of technology and communications. This transformation will not be painless, however, as the reference to the shards of mirror in the viewers' eyes suggests, but it will certainly force the dominant culture to address the uncomfortable aspects of the reflection it contemplates and acknowledge the presence of alternative cultures whose creative use of transnational communications devices has secured them a place beyond the margins.

\section{Notes}

1 "Globalization is most effectively seen in the audiovisual world: music, cinema, television and computers are being reordered . . . so that they are disseminated to the entire planet. The multimedia system that partially integrates these four fields offers unprecedented possibilities for transnational expansion in even peripheral cultures” (my translation).

2 "In the United States, the passive stereotypes of the sleepy Mexican, the greaser and the border vixen were defrosted in the decade of the 1980s. Since the (still illegal) implementation of Proposition 187 and the new anti-immigrant fever, a new stereotype of the Mexican has 
emerged: the recently born robo-Mexican embodies the xenophobic fears of a formerly First World society (in the process of becoming the Third World) and this new stereotype has come to replace the formidable Soviet enemy on the big screen and on Super Nintendo II. This new stereotype is the Mexterminator, alias Mad Mex ... His sinister mission involves no more and no less than the re-conquest of the Southeast of the United States, and no one-not Stallone, not Schwarzennegger, not Pete Wilson—can stop him” (my translation).

\section{References}

Alcaraz, Lalo. 2004. Migra Mouse: Political Cartoons on Immigration. New York: RDV Books. Camplis, Francisco X. 1992. Towards the Development of a Raza Cinema (1975). In Chicanos and Film: Representation and Resistance, ed. Chon A. Noriega, 284-303. Minneapolis: University of Minnesota Press.

Culture Clash. 2003. Bordertown. New York: Theatre Communications Group.

Fox, Claire F. 1999. The Fence and the River: Culture and Politics at the U.S.-Mexico Border. Minneapolis: University of Minnesota Press.

Fox, Claire F. 1996. Mass Media, Site Specificity, and the U.S.-Mexico Border: Guillermo Gómez-Peña’s Border Brujo (1988, 1990). In The Ethnic Eye: Latino Media Arts, ed. Chon A. Noriega and Ana M. López, 228-244. Minneapolis: University of Minnesota Press.

García Canclini, Néstor. 2005. La globalización imaginada. Buenos Aires: Editorial Piadós.

Gómez-Peña, Guillermo. 2002. El Mexterminator: Antropología inversa de un performancero postmexicano. Mexico: Editorial Océano de México.

Gómez-Peña, Guillermo. 2000. Dangerous Border Crossings: The Artist Talks Back. New York: Routledge. 
Gómez-Peña, Guillermo. n.d. On the Other Side of the Mexican Mirror. http://www.pochanostra.com/antes/jazz_pocha2/mainpages/otherside.htm.Accessed_on September 2, 2008.

Green, Duncan. 1997. Faces of Latin America. London: Latin American Bureau. Hopper, Paul. 2007. Understanding Cultural Globalization. Cambridge: Polity Press. Johnson, William. 1972. Focus on the Science Fiction Film. New Jersey: Prentice Hall. López, Ana M. 1990. At the Limits of Documentary: Hypertextual Transformation and the New Latin American Cinema. In The Social Documentary in Latin America, ed. Julianne Burton, 403-432. Pittsburgh: University of Pittsburgh Press.

Kelly, Philip. 2003. Canadian-Asian Transnationalism. The Canadian Geographer 3: 209-218.

Mendieta, Eduardo. 2003. A Latino Philosopher Interviews a Chicano Performance Artist: Eduardo Mendieta and Gómez-Peña. Neplanta: Views from South 2.3: 539-554.

Ramírez Berg, Charles. 2002. Latino Images in Film: Stereotypes, Subversion and Resistance. Austin: University of Texas Press.

Rony, Fatimah Tobing. 1996. The Third Eye: Race Cinema, and Ethnographic Spectacle. Durham: Duke University Press.

Sassen, Saskia, ed. 2007. Deciphering the Global: Its Scales, Spaces and Subjects. New York: Routledge.

Suchlicki, Jaime. 2008. Mexico: From Montezuma to the Rise of the PAN. Virginia: Potomac Books.

West, Dennis, and Crowdus, Gary. 1988. Cheech Cleans up His Act: An Interview with Richard ‘Cheech’ Marin. Cineaste 16.3: 34-47. 
Wood, Alylish. 2002. Technoscience in Contemporary American Film: Beyond Science Fiction. Manchester: Manchester University Press.

Wuthnow, Robert, and Offutt, Stephen. 2008. Transnational Religious Connections. Sociology of Religion 69.2: 209-232. 